\title{
AVERAGE VOTING MEMBERS AND OTHER "BENIGN FICTIONS": THE RELATIVE RELIABILITY OF COMMITTEE REPORTS, FLOOR DEBATES, AND OTHER SOURCES OF LEGISLATIVE HISTORY
}

\author{
George A. Costello*
}

The Supreme Court is beginning to reexamine old approaches to statutory interpretation. With the increased mass and complexity of federal statutes over the last six decades, courts have turned imcreasingly to legislative history when faced with issues of statutory interpretation. The eagerness of many courts to examine congressional materials prompted the joke that under the "American rule," examination of statutory text is permissible only when legislative history is ambiguous. Now underway in the Supreme Court is a challenge, led by Justice Scalia, to routime reliance on legislative history as an aid to statutory interpretation. This challenge extends beyond merely curbing excesses occasioned by overreliance on legislative history. With imcreasing frequency, the Court emphasizes statutory language and structure and deemphasizes the role of legislative history. ${ }^{1}$ Also under question is the relative imterpretational

* Legislative Attorney, Congressional Research Service, Library of Congress. B.A., Johns Hopkins University, 1966; J.D., Duke Law School, 1969. The views expressed in this Article are those of the author, and do not necessarily represent those of the Congressional Research Service.

1. This trend, begun well before Justice Scalia's arrival on the Court, appears not so much from the relatively easy eases in which statutory language is deemed plain and unambiguous, see, e.g., United States v. Ron Pair Enters., 109 S. Ct. 1026, 1027 (1989) (comma placement dictates result); United States v. Locke, 471 U.S. 84, 96-98 (1985) (requirement that claims be filed prior to Dec. 31 does not allow filing on Dec. 31), as from other cases in which legislative history is consulted only to determine if there is a "clear statement" of congressional intent contrary to the Court's reading of the statute's meaning, see, e.g., INS v. Cardoza-Fonseca, 480 U.S. 421,432 n.12 (1987) (Immigiation Act's differently worded standards for political asylnm and for withholding of deportation carry different ineanings), or in which legislative history is not consulted at all in spite of disputed nreaning, see, e.g., Patterson v. McLean Credit Union, 109 S. Ct. 2363, 2369 (1989) (holding that clainis of racial harassnient in the workplace are not covered by 42 U.S.C. $\$ 1981$ ). See also Public Citizen v. Department of Justice, 109 S. Ct. 2558, 2576 (1989) (Kennedy, J., concurring) (challenging legislative history materials as "unauthoritative"). For explanations of the clear stateinent trend, see Wald, Some Observations on the Use of Legislative History in the 1981 Supreme Court Term, 68 IowA L. REv. 195, 215 (1983); Comment, Intent, Clear Statements, and the Common Law: Statutory Interpretation in the Supreme Court, 95 HARv. L. REv. 892 (1982).

Another way in which the Court places greater emphasis on statutory text is to look at the language and structure of the statute as a whole in order to place particular language in context and thereby narrow or confirm its meaning. This nethod, dubbed "structuralism" by then Judge (now 
weight accorded the different congressional materials when the Court does look to legislative history. In several vehement opinions, Justice Scalia has challenged the preeminent position of committee reports as being the most reliable source of legislative history for explainmg statutory meaning. Cominentators have raised similar questions, suggesting thiat courts should focus on the average voting Member rather than on the proponents of legislation. ${ }^{2}$

Legal scholarship is replete with analysis of threshold issues surrounding when and for what purposes courts should consult legislative history. ${ }^{3}$ Less attention lias been paid to low courts, when they do see fit to consult legislative history, should differentiate among the various sources of legislative history. Part I of this Article describes the hierarcliy courts liave establislied among the principal sources of legislative history (committee reports liave been considered the inost reliable, floor

Solicitor General) Starr in Of Forests and Trees: Structuralism in the Interpretation of Statutes, 56 GEO. WASH. L. REv. 703, 708-09 (1988), is not new-except perhaps when it is used as a reason to avoid all reference to legislative history. Justice Scalia sumnnarized the general approach. Pointing out that statutory construction is "a holistic endeavor," he notes that "[a] provision that may seein ambiguous in isolation is often clarified by the remainder of the statutory scheme." United Sav. Ass'n y. Timbers of Inwood Forest Assocs., 484 U.S. 365, 371 (1988). The Court illustrated how structuralisin can work in United States v. Fausto, 484 U.S. 439 (1988), authored by Justice Scalia. The Fausto Court found in the structure of the Civil Service Reform Act "a clear congressional intent to deny" judicial review to a category of employees who it previously had held were entitled to judicial review under other statutes. Id. at 447. This finding was in spite of the fact that, as dissenting Justice Stevens objected, there was "not a single word in either the text or the legislative history ... that purports to withdraw or curtail any judicial remedy that was previously available." Id. at 455.

2. Easterbrook, The Role of Original Intent in Statutory Construction, 11 HARv. J.L. \& PuB. PoL'y 59, 63 (1988); Starr, Observations About the Use of Legislative History, 1987 DUKE L.J. 371, 375-76.

3. For some of the classics, see Frankfurter, Some Reflections on the Reading of Statutes, 47 Colum. L. REv. 527, 529 (1947); Jackson, The Meaning of Statutes: What Congress Says or What the Court Says, 34 A.B.A. J. 535, 536 (1948); Landis, A Note on "Statutory Interpretation," 43 HARV. L. REV. 886, 888 (1930); Radin, Statutory Interpretation, 43 HARV. L. REV. 863, 867 (1930). More recent offerings, in addition to those already noted, include Easterbrook, Statutes' Domains, 50 U. CHI. L. REv. 533; 544 (1983); Eskridge, Public Values in Statutory Interpretation, 137 U. PA. L. REv. 1007, 1010 (1989); Eskridge, Dynamic Statutory Interpretation, 135 U. PA. L. Rev. 1479, 1482 (1987); Farber \& Frickey, Legislative Intent and Public Choice, 74 VA. L. REV. 423, 424-25 (1988); Grabow, Congressional Silence and the Search for Legislative Intent: $A$ Venture into "Speculative Unrealities," 64 B.U.L. REv. 737, 741 (1985); Hatch, Legislative History: Tool of Construction or Destruction, 11 HARv. J.L. \& PuB. PoL'Y 43, 45, 48 (1988); Maltz, Statutory Interpretation and Legislative Power: The Case for a Modified Intentionalist Approach, 63 TUL. L. REV. 1, 22-28 (1988); Mikva, A Reply to Judge Starr's Observations, 1987 DuKe L.J. 380, 386; Posner, Legal Formalism, Legal Realism, and the Interpretation of Statutes and the Constitution, 37 CASE W. RES. L. REv. 179 (1986); Tribe, Judicial Interpretation of Statutes: Three Axioms, 11 HARV. J.L. \& PUB. POL'Y 51, 52-54 (1988). For the Reagan Adininistration's contribution to the ongoing debate, see Office of Legal Policy, Department of Justice, Using and Misusing Legislative History: A RE-Evaluation of the Status of Legislative History in STatutory INTERPRETATION, REPORT TO THE ATTORNEY GENERAL (1989). 
debates and hearings less so). ${ }^{4}$ Part II documents criticism of the traditional approach to legislative history and examines the proffered alternatives. ${ }^{5}$ At first glance it may appear that two principal alternatives are suggested by Justice Scalia and other critics-specifically, that less rehance should be placed on legislative history altogether and that the relative importance of committee reports and floor debates should be reversed-but in reahty these two approaches are interrelated. Moreover, examination of the relative rehability of the different sources of legislative history suggests better support for the first alternative than for the second. The case for considering floor debates as inherently inore reliable than committee reports is weak. It is important to examine the underlying objections to reliance on committee reports, for the same objections used in support of arguments favoring floor debates also underlie arguments for reduced reliance on legislative history of any kind.

The emphasis to date on the threshold issues reflects relative importance: once the purpose for which legislative history should be consulted has been determined, one can identify better which (if any) sources of legislative history may provide the most reliable answers. Nonetheless, renewed focus on the different sources and uses of legislative history may help illuminate the threshold debate. Unless "every smippet" of legislative history is equated with congressional intent, and congressional intent is to be equated with enacted policy, consideration of inherent limitations and relative reliability of various sources of legislative history can provide a useful background for the development of a general approach to reliance on legislative history.

\section{Traditional Approach to the Relative Weight Given Committee Reports, Floor Debate, and Hearings}

Over the years, courts looking to legislative history to explain statutory meaning developed a rough hierarchy of interpretational weight that should be given to the different elements of legislative history. Traditionally-and as a general matter-committee report explanations are considered more persuasive and rehable than statements made during floor debates or during hearings on a bill. Within the category of floor debates, statements of sponsors and explanations by floor managers usually are accorded the most weight, and statements by other committee members are next in importance. Statements by Members not associated with sponsorship or committee consideration of a bill are accorded little weight and statements by bill opponents generally are discounted or con-

4. See infra notes 6-103 and accompanying text.

5. See infra notes 104-40 and accompanying text. 
sidered unreliable. Committee hearings are generally treated the same way as floor debates: Statements by sponsors or drafters are most persuasive, views of other witnesses seldom carry much weight, and fears of opponents usually are dismissed as unrehable.

Caveats such as "generally" or "usually" are necessary for several reasons. To begin with, it is more accurate to refer to most of the precedents discussed below as conventions rather than as "rules" of construction. Some precedents are fairly well established; others are more tenuous. And even if a convention is well established, it may be inapplicable in many contexts. Thus, the origin of the statutory language in question may preclude reference to some of the customary sources of legislative history. If, for example, the language has been added by floor amendment, then the earhier hearings and committee report in the same House will shed no direct hight on its meaning. Similarly, if one House added language to the bill after it passed the other House, then one can focus on the deliberations of the second House, the conference report (if there is one), and the later consideration of the added language in the House where the bill originated.

A related caution: The clarity of statutory text and pertinent legislative history varies from case to case and from issue to issue. What at first glance may appear to be inconsistent application of the rules or conventions actually may be consistent application under distinguishable circumstances. Likewise, opinions frequently differ as to the meaning of various bits and pieces of legislative history and as to how they relate to the issue at hand. Thus, although the general rule is that a committee report's explanation of the bill will be deeined more persuasive than a conflicting explanation made during floor debate, a court may view the floor explanation as more pertinent to its inquiry, and dismiss the committee explanation as "not on point" and hence not actually conflicting.

A statistical survey of the Supreine Court's references to legislative history ${ }^{6}$ revealed that the relative frequency of citation of the different sources of legislative history roughly parallels the relative interpretational weight the Court attributes to them. Thus, during the period studied (1938-1979), almost fifty percent of the Court's references to legislative history inaterials were to committee reports (including reports of conference committees), approximately twenty percent were to floor debates, and around fifteen percent were to hearings. References to bills, House and Senate docuinents, and various historical sources inake up the remainder.

6. Carro \& Brann, The U.S. Supreme Court and the Use of Legislative Histories: A Statistical Analysis, 22 JURIMETRICS J. 294 (1982). 


\section{A. Committee Reports and Action}

That committee reports constituted nearly fifty percent of the Supreme Court's references to legislative history materials is no accident. Ordinarily, committee reports are considered the most rehiable and persuasive element of legislative history. ${ }^{7}$ Committee reports are well-regarded because, in the words of Justice Harlan, they represent the "considered and collective understanding of those Congressmen involved in drafting and studying proposed legislation."8 Even Justice Jackson, strongly opposed to reliance on legislative history, would have made an exception for committee reports: "presumably [committee reports are] well considered and carefully prepared." As a result, "unambiguous" committee report explanation has been preferred over floor debate-even when the bill's floor inanager tendered a contradictory interpretation. ${ }^{10}$ However, because the language in committee reports is not approved by vote and custoinarily is written by staff, it may be appropriate to deterinine whether a floor manager has attempted to correct a committee report explanation. ${ }^{11}$

There are limits to the Court's willingness to rely on committee report language, and most of these trace to the inherent limitations of any legislative history. The "considered and collective understanding" of committee meinbers is valuable to explain statutory langnage, but it loses persuasive force when it departs from its statutory base. To carry weight, congressional explanations must explain the statutory text at hand. Committee "understandings" and directives to administering agencies, as well as explanations of language enacted by a previous Congress, lose probative force when they depart froin the statutory text approved by the committee. Otherwise, the constitutional procedures for lawinaking could be frustrated; if constitutional bicameralisin and pre-

7. See Thornburg v. Gingles, 478 U.S. 30, $44 \mathrm{n} .7$ (1986) ("We have repeatedly recognized that the authoritative source for legislative intent lies in the committee reports on the bill.").

8. Zuber v. Allen, 396 U.S. 168, 186 (1969), quoted with approval in, Garcia v. United States, 469 U.S. 70,76 (1984).

9. Schwegmann Bros. v. Calvert Distillers Corp., 341 U.S. 384, 396 (1951) (Jackson, J., concurring).

10. Chandler v. Roudebush, 425 U.S. 840,858 n.36 (1976).

11. Occasionally courts have relied on a floor manager's or sponsor's contradiction of a committee report. See, e.g., Chicago, Milw., St. Paul \& Pac. R. Co. v. Acme Fast Freight, 336 U.S. 465, 472-75 (1949) (uncontradicted statement of ranking minority member preferred over committee report explanation). Acme is only a minor aberration because the committee's report had not been submitted to committee members, the committee vote reporting the bill had been unanimous, and the ranking minority member's unchallenged views represented the only detailed explanation of the provision at issue. Similarly, the court in FEC v. Rose, 806 F.2d 1081, 1089-90 (D.C. Cir. 1986), dismissed as "uninformed ipse dixit" a statement in a House committee report that was contradicted by sponsors, without refutation, during House and Senate debate on the bill. 
sentment requirements make invalid a one-House legislative veto, ${ }^{12}$ then the report of a single committee may not be accorded the force of law. ${ }^{13}$ As the Court recently put it, "unenacted approvals, beliefs, and desires are not laws." 14 In Isla Petroleum, the Court found no statutory basis for following suggestions in legislative history that Congress may have intended to preempt state law. Similarly, the Court has dismissed, as purely "precatory," a committee report directive that federal activities "should" be coordmated with state planning when the accompanying bill plainly exempted federal activities from such coordination. ${ }^{15}$ And in the "Snail Darter" case, the Court refused to honor an appropriations committee's "understanding" that the Endangered Species Act (ESA) did not bar completion of a dam for which appropriations were being made, since the Court read the ESA differently than the committee and the appropriations bill failed to exempt the project from the ESA. ${ }^{16}$

Pierce v. Underwood offers a clear example of committee report language outpacing statutory text. ${ }^{17}$ A committee report on 1985 amendinents to the 1980 Equal Access to Justice Act voiced approval of a minority rule (adopted by one circuit and rejected by twelve) that interpreted a provision left unchanged by the 1985 amendments. The Court, speaking through Justice Scalia, rejected rehance on this statement, largely because "it is not an explanation of what the 1985 Committee drafted," and "reenacting precisely the same language would be a strange way" to change a minority rule into the majority rule. ${ }^{18}$ Although the Court is willing in some circumstances to hold that reenactment of statutory language without change incorporates an estabhished judicial or admimistrative interpretation, even in the absence of affirmative indications of congressional imtent to do so, ${ }^{19}$ it apparently is unwilling to attribute to Congress a single committee's expressed preferences for minority interpretations.

Sometimes included in committee reports are "minority," "dissenting," "supplemental," or "additional" views. These additions allow committee members, who do not vote on the language of committee re-

12. INS v. Chadha, 462 U.S. 919 (1983).

13. See In re Sinclair, 870 F.2d 1340, 1344-45 (7th Cir. 1989).

14. Puerto Rico Dep't of Consumer Affairs v. Isla Petroleum Corp., 485 U.S. 495, 501 (1988).

15. Secretary of the Interior v. California, 464 U.S. 312, 323 n.9 (1984).

16. Tennessee Valley Auth. v. Hill, 437 U.S. 153, 191 (1978).

17. 487 U.S. 552 (1988).

18. Id. at 564; see also Public Employees Retirement Sys. v. Betts, 109 S. Ct. 2854, 2861 (1989) (refusing to accord weight to 1978 committee report's expression of disapproval of 1977 court decision because 1978 amendments did not modify the "relevant" statutory language in the Age Discrimination in Employment Act).

19. See, e.g., Lorillard v. Pons, 434 U.S. 575, 582 (1978) (finding congressional intent to allow private actions under the Age Discrimination in Employment Act). 
ports, to challenge report explanations or offer different perspectives. In this manner, other Members are alerted that the bill or report explanation may be controversial. ${ }^{20}$ Although these views cannot carry the same weight as those endorsed (or acquiesced in) by the committee as a whole, they nonetheless are cited from time to time in court opinions. Typically, views of bill opponents are discounted, whether expressed in hearings, committee reports, or floor debates. 21 Nevertheless, "mmority" or "dissentimg" views appended to committee reports can be useful to demonstrate general agreement on a particular interpretation, ${ }^{22}$ or to establish that there was focused debate on a position advocated by opponents, but rejected by the committee. ${ }^{23}$ Reference to "additional" views has not been as circumscribed; on occasion the Court has cited them as views of bill proponents. ${ }^{24}$

Conflicts between House and Senate report explanations of identical bill language are relatively infrequent, because different positions often result im different bill language and clear resolution by way of conference report or other direct vote. Absent congressional reconciliation of such conflicting explanations, a court inay favor one explanation over another as better reflecting its own reading of the statute. ${ }^{25}$ However, if there is a direct conflict between opposing committee report explanations that the Court views as equally plausible, it can apply the general rule placing rehance on whichever report was (in theory, at least) before both Houses. For example, where the House passed a Senate bill without amendinent, the Court rehed on the Senate report on the theory that its explanation,

20. See C. Tiefer, Congressional Practice and Procedure 184 (1989).

21. See infra notes 52-86 and accompanying text.

22. See, e.g., Smith v. Robinson, 468 U.S. 992, 1020-21 (1984) ("minority views" cited as showing agreement with committee majority that local school finances should not be overburdened by requirements for education of handicapped children); California v. United States, 438 U.S. 645, 66970 (1978) ("minority views" amplify report's solicitude for traditional authority of states to regulate waters within their borders).

23. See, e.g., Malone v. White Motor Corp., 435 U.S. 497, 508-09 (1978) (objections in "minority views" to effect that ERISA's pension disclosure rules would undermine collective bargaiming supports conclusion that Congress intended no exception for collectively bargained plans); Chandler v. Roudebush, 425 U.S. 840, 850-53 (1976) ("focused debate" and "thorough and ineticulous consideration" of a particular issue, revealed by comınittee inajority disagreement with "minority views," evidences informed congressional choice between two positions).

24. See, e.g., Garrett v. United States, 471 U.S. 773, 783 (1985) (one of four signers of "additional views" was a sponsor of the language in question); Regents of the Univ. of California v. Bakke, 438 U.S. 265, 335 n.2 (1978) (Brennan, White, Marshall, \& Blackmun, J. J., concurring) ("Additional Views of Seven Representatives" cited as views of bill "proponents").

25. For example, in Beech Aircraft Corp. v. Rainey, 109 S. Ct. 439 (1988), the Court, adhering to a view it believed to be more consistent with the language of a rule of evidence and the commentary by the Advisory Committee on Proposed Rules, followed the interpretation of the Senate Judiciary Committee rather than the "diametrically opposite" and unreconciled House Judiciary Committec interpretation. Id. at $447-48$. 
unlike that of the House report, had been before both Houses for consideration. ${ }^{26}$

Committee action unaccompanied by any explanation may be ineffective. Rejecting an arguinent that unexplained committee changes in bill language should be given significance, the Court declared that " $t]$ he interpretation of statutes cannot safely be made to rest upon mute intermediate legislative maneuvers."27

Ordinarily, the committee report is the only written record available to explain what action a committee has taken on a bill, since transcripts of committee inarkup sessions are not commonly available. If the transcripts are available, however, courts may be willing-or even eager-to refer to thein. ${ }^{28}$ Transcripts may contain an explanation for what otherwise could be dismissed as "mute intermediate legislative maneuvers."

Without mentioning the novelty of published coinmittee markup transcripts as sources of legislative history, the Supreme Court has quoted them extensively. ${ }^{29}$ In Regan v. Wald, the Court described "a full exammation of legislative history" as including "the subcommittee hearings, markup sessions, floor debates, and House and Senate reports." ${ }^{30}$ Although the Court found the legislative history inadequate "to overcome what seems to us to be the clear, generic meaning" of the statutory language, ${ }^{31}$ the case signals the Court's willingness to consider published markup transcripts as an element of legislative history.

If unpublished, the markup transcript may raise additional questions. Since these issues have not been explored directly in litigation, however, the following discussion is tentative. If the transcript is unpublislied at the time of consideration and passage of the bill by either the full House or Senate, then it is unlikely that the markup proceedings (to the extent tliat they are not summarized in the committee report) will have come to the attention of the Members not present at markup. In that case, a court miglit liave difficulty attributing tlie views expressed in

26. Department of the Air Force v. Rose, 425 U.S. 352, 366 (1976). Application of this rule would have led to the opposite result in Beech Aircraft. For criticism of the underlying premise of the rule, see Mikva, Reading and Writing Statutes, 28 S. TEx. L. REv. 181, 187 (1986) ("If the legitimacy of the legislative process turned on how many House members would ever deign to read a committee report of the other body, the process would be even more suspect than it is.").

27. Trailmobile Co. v. Whirls, 331 U.S. 40, 61 (1947); accord Mead Corp. v. Tilley, 109 S. Ct. 2156, 2162 (1989) (refusal to "attach decisive significance to the disappearance of onc word from an unenacted bill").

28. It has been observed that committee markups are key decision points in the lcgislative process, but that ironically it is "the more diffused, less critical parts of the process-hearings and debates-[that] are [routinely] transcribed." Wald, supra note 1, at 202.

29. Regan v. Wald, 468 U.S. 222, 236 (1984).

30. Id. at 238 (emphasis added).

31. Id. at 237. 
the markup to Congress as a whole. ${ }^{32}$ However, the same situationcongressional consideration and passage antedating a published recordalso frequently occurs for hearings and sometimes occurs for reports. Courts rely on the hearing record and on committee reports for indications of congressional intent while seemingly ignoring the timing of publication. ${ }^{33}$

A second problem arises if the markup transcript remains unpublished. Litigants may question the fairness of being bound by "legislative history" that is not part of the readily available (printed) public record. As long as unpublished transcripts kept on file by committees are available on an equal basis to both sides in hitigation, the availability problem would not necessarily prejudice individual cases. Still, courts may question whether the ultimate meanimg of statutes should rest on materials generally unavailable to those who will either implement them or be bound by them. ${ }^{34}$

Unpublished committee markup transcripts have been rehed on by at least one federal court, ${ }^{35}$ although the judge who authored that opinion later confessed to "some unease" over the usage. ${ }^{36}$

\section{B. Conference Committee Action and Reports}

Frequently the action of the conference committee is the critical stage in shaping legislation. It is here that bills subject to a conference take on their final forın, ${ }^{37}$ and differences in House and Senate versions of the bills are reconciled. If the conference committee explains its action clearly, then courts will not hesitate to rely on that explanation. ${ }^{38}$ In the words of a lower court, the conference report is "especially persuasive evidence of congressional intent [because it] represents the final word on the final version of a statute." 39 Unfortunately, however, explanations of

32. See, e.g., Mohasco Corp. v. Silver, 447 U.S. 807, 823-24 (1980) (Congress could not have relied on analysis placed in Congressional Record after passage of bill).

33. Justice Scalia's opposition to reliance on committee report explanations is based in part on this very problem. See Blanchard v. Bergeron, 109 S. Ct. 939, 947 (1989) (Scalia, J., concurring); Note, Justice Scalia's Use of Sources in Statutory and Constitutional Interpretation: How Congress Always Loses, 1990 Duke L.J. 346.

34. See Jackson, supra note 3 , at 538 .

35. Borrell v. United States Int'l Communications Agency, 682 F.2d 981, 988 (D.C. Cir. 1982) (relying on unpublished nuarkup to support conclusion that Congress created no private right of action for whistle blowers).

36. IVald, supra note 1 , at 202.

37. The conference report represents the final form of legislation because of the congressional practice that reports be adopted or rejected as a whole without amendnent. See C. TIEFER, supra note 20 , at 818 .

38. See, e.g., Leedoin v. International Union, 352 U.S. 145, 149-50 (1956) (relying on conference report itself and on conferee's explanation on floor).

39. Planned Parenthood Fed'n v. Heckler, 712 F.2d 650, 657 n.36 (D.C. Cir. 1983). 
conference committee action are often brief, cryptic, or totally absent. In such instances, courts inay attempt to interpret the language so as not to expand the scope of the reconciled House and Senate versions.

Technically, the report of the conference coinmittee is merely the text of the recommended bill, and the accompanying "statement of the managers" explains the committee's action. Alınost invariably, courts employ the shorthand "committee report" when referring to the explanatory statement of the managers; that usage is also employed here. It must be noted, however, that the Supreme Court has distinguished between the two. In National Association of Greeting Card Publishers $v$. United States Postal Service, the Court characterized a managers' statement as not having the "status of a conference report."40 At issue was a statement by managers on the part of the House, rather than the joint explanatory stateinent now required under the rules of both Houses. Therefore, it is unclear whether the Court's distinction has any significance when apphed to a joint explanatory statement. Cases involving interpretation of statutes enacted under the old conference committee rules can still arise, however, so it reinains important to determine whether the explanation accompanying a report is a joint explanatory statement or merely a statement of the managers on the part of the House. There is precedent for mimimizing the significance of a statement by House managers when Senate managers, in explaining the conference bill on the floor, demed that they had concurred in the House inanagers' interpretation. ${ }^{41}$

When one House's version of disputed bill language is accepted in its entirety over the other body's version, the conference report often notes that the other House "recedes." Absent further explanation, courts may assume the adopted version was chosen for substantive reasons. ${ }^{42}$ However, there is no such imphication when specific language in one version is dropped in favor of general language broad enough to en-

40. 462 U.S. 810,832 n.28 (1983). Note as well that Justice Kennedy recently referred to the text of "the Conference Committee Report" as "the most obvious place" for finding the statement of congressional findings and purposes that was later enacted into law. Public Citizen v. Department of Justice, 109 S. Ct. 2558, 2577 (1989) (Kennedy, J., concurring).

41. District of Columbia Fed'n of Civic Ass'ns v. Volpe, 434 F.2d 436, 444 n.38 (D.C. Cir. 1970) (House managers' statement, contradicted by Senate managers, "can only be said to represent the personal opinions of those who signed it"). The concurring opimion in the same case phrased the matter differently, but reached the same result: The House managers' statement, although "entitled to respect in determining the legislative imtent, is not . . . entitled to the weight of a conference report, smce it was not signed by a majority of the Senate conferees." Id. at 448 \& n.4 (Bazelon, J., concurring).

42. North Haven Bd. of Educ. v. Bell, 456 U.S. 512, 528-29 (1982). 
coinpass the specific. ${ }^{43}$ This interpretation recognizes that one of the conference committee's functions is to remove duplication, and that not all unexplained actions may properly be attributed to the committee's duty to resolve differences.

When the conference committee, without explaining its reasons, discards botli House and Senate versions and rewrites the language of a provision, the Court may be reluctant to read into the new language a major change in ineaning. Instead, tlie Court inay explain the provision as falling within the same scope as tlie House and Senate bill antecedents. For exainple, in Public Citizen v. Department of Justice, the Court interpreted an explanation that a House version liad been adopted "witl inodification" as not significantly changing the perceived thrust of the eartier language-even though the modification could have been read to broaden the provision's coverage. ${ }^{44}$ Similarly, in Secretary of the Interior v. California, the Court interpreted general language, added by the conference committee witlout explanation, to have the same narrow geographic limitation that was explicit in previous bill versions. ${ }^{45}$ What appeared "at first sight" (i.e., on its face) to be an expansion im scope of coverage had a "plausible" explanation of "simple coinpromise" between House and Senate bills. ${ }^{46}$ And in a 1985 case, Chemical Manufacturers Association v. NRDC, the Court again explained general language, added in conference, in terms of inore limited language in bill antecedents. ${ }^{47}$ Thus, while there is no assurance tliat in similar circumstances the Court

43. Louisiana Pub. Serv. Comm'n v. FCC, 476 U.S. 355, 378 n.6 (1986); Pattern Makers v. NLRB, 473 U.S. 95, 110-11 (1985).

44. 109 S. Ct. 2558, 2570 (1989). At issue was a change in coverage of the Federal Advisory Committee Act. The House bill had applied to committees "established" by either the President or by executive agencies, whereas the Senate bill had applied to committees "establislied or organized." The conference committee substituted "establislied or utilized" by either the President or by executive agencies. Id. The Court dismissed this change by noting that the conference committee "offered no indication tliat the modificatiou was significant, let alone that it would substantially broaden FACA's application." Id.

45. 464 U.S. 312,324 (1984).

46. Id. at 322-23. Drafters changed the bill in conference to require that various federal activities "direetly affecting" the coastal zone be coordinated with state planning. Botl House and Senate versions had limited the apphicability of the requirenent to activities "in" the coastal zone. The difference lay in the definition of "coastal zone": The Senate bill excluded federal enclaves and the House bill included them. The conference substitute used the Senate definition of coastal zoue, excluding federal enclaves, but clianged "in" the coastal zone to "directly affecting" the coastal zone. The Court interpreted the new provision to apply ouly to activities that emanated from federal enclaves witlin the outer boundaries of the coastal zone. Therefore, it was inapplicable to leasing activities on the outer continental shelf beyond the boundaries of the coastal zoue. Id. at 322-24.

47. Chemical Mfrs. Ass'n v. NRDC, 470 U.S. 116, 125-26 (1985). The Court lield that a directive of the EPA did not "Inodify" a pollution standard and did not prohibit issuance of a "variance" that recognized improper classification of a pollution source. Agreeing with the EPA, the Court held that the directive was explained instead in terms of the antecedent bills' prohibitions against issuing otlier kinds of varianees based on economic circumstances or impact on water quality. See 
will rely heavily on legislative history rather than on statutory text, ${ }^{48}$ when it does look to legislative history the Court may accord importance to the conference committee's primary role in resolving differences between House and Senate bills. ${ }^{49}$

If there is no official record (e.g., a transcript) of a committee's consideration and rejection of an amendment, the unexplained rejection is entitled to no weight in statutory construction. In refusing to consider an argument based on a conference committee's rejection of an amendment, the Court noted that the measure had "never [been] introduced in either House . . . and [had] not even appeared in the Congressional Record," and hence "has under our precedents nothing whatever to do with Congress's intent." 50

\section{Floor Debates}

Statements made by Members during general debate on a bill following its report froin committee are considered less persuasive than the committee report. If there is a conflict, then the "considered and collective understanding" of the committee takes precedence over the views expressed during the floor debate-since these views "reflect at best the understanding of individual Congressmen." 51 The Court added, "It would take extensive and thoughtful debate to detract from the plain thrust of a committee report."52 Frequently, however, issues not addressed by committee reports are discussed during the floor debate, and here the views of Members closely associated with the legislation through either sponsorship or committee review can be helpful.

An important consideration that bears on the value of floor debates is that extemporaneous remarks are often less carefully considered than the written word. As the Court explained, "In construing laws we have been extremely wary of testimony before committee hearings and of de-

also Mead Corp. v. Tilley, 109 S. Ct. 2156, 2162 (1989) (unexplained deletion of word by conference committee termed a "mute intermediate legislative maneuver [ 1 ").

48. Indeed, these cases seem counter to the trend toward increased einphasis on statutory text. In each case, however, the Court premised its excursion into legislative history on a finding of textual ambiguity. See Public Citizen, 109 S. Ct. at 2565; Chemical Mfrs., 470 U.S. at 125-26; Secretary of Interior v. California, 464 U.S. at 321.

49. The Court has not yet finetuned its approach by recognizing the broad scope allowed con. ferees dealing with an "amendinent in the nature of a substitute" rather than so-called "cut-and. bite" amendinents. See C. TIEFER, supra note 20, at $812-16$. Such recognition might have made the Court's "sinple coinpromise" conclusion somewhat less certain in Secretary of Interior v. California, 464 U.S. at 312. However, the larger point is that the Court requires such significant changes in legislation to be explained by the conference committee.

50. City of Milwaukee v. Illinois, 451 U.S. 304, 332 n.24 (1981).

51. Zuber v. Allen, 396 U.S. 168, 186 (1969).

52. Id. 
bates on the floor of Congress save for precise analyses of statutory phrases by the sponsors of proposed laws." 53 A corollary is that prepared statements offered during floor debate are sometimes accorded more importance than are extemporaneous remarks. For example, in North Haven Board of Education v. Bell, the Court relied on a sponsor's statements about a floor amendment as "tlie only authoritative indications of congressional intent," explaining that tlie statements "were made on the same day the amendment was passed, and some ... were prepared ratler than spontaneous remarks." 54 However, newspaper or magazine articles inserted in the Record by unanimous consent apparently should not be equated witl prepared statements actually read into the Record. In a 1986 opinion, tlie Court dismissed as "not 'legislative history' im any meaningful sense of the term" a banking journal article that a Member liad "entered into the Congressional Record." ss Althougli the Court did not explain its reasoning, it is probably significant that the Member who requested insertion did not summarize or otlierwise indicate the content of the article.

Witlin the category of floor debate, some Members are inore equal than others. Statements by sponsors and floor managers carry the most weight, statements by Members not associated witl eitlier formulation or committee consideration of the bill warrant little weight, and statements by bill opponents usually are not taken at face value.

Altliough " $[t]$ lie remarks of a simgle legislator, even the sponsor, are not controllimg in analyzing legislative history," and other relevant sources must be considered as well, ${ }^{56}$ the explanation of tlie sponsor can be "an authoritative guide" to congressional intent wlien the language was added by floor aunendment and there is no committee report explanation. 57 The Court lias lield that a sponsor's remarks are "more persuasive" than conflicting views of supporters in the other House. ${ }^{58}$ There are even some circumstances in which silence of sponsors can be deemed significant, as, for example, an indication that the sponsor did not intend radical cliange to the statutory sclieme. ${ }^{59}$ On the otlier liand, the Court

53. S \& E Contractors, Inc. v. United States, 406 U.S. 1, 13 n.9 (1972).

54. 456 U.S. 512, 527 (1982). The Court also recently contrasted oral statements with statutory text: "Oral testimony of witnesses and individual Congressmen, unless very precisely directed to the intended meaning of particular words in a statute, ean seldom be expected to be as precise as the enacted language itself." Regan v. Wald, 468 U.S. 222, 237 (1984).

55. Board of Governors of the Federal Reserve Sys. v. Dimension Fin. Corp., 474 U.S. 361, 372 (1986).

56. Chrysler Corp. v. Brown, 441 U.S. 281, 311 (1979).

57. North Haven, 456 U.S. at 526-27.

58. Steiner v. Mitchell, 350 U.S. 247, 254 (1956).

59. For example, in National Woodwork Mfrs. Ass'n v. NLRB, 386 U.S. 612, 640 (1967), the Court stated: 
realizes that sponsors or other proponents may indulge in "puffing," either exaggerating the benefits or minimizing the harm to various interests in an attempt to secure votes for passage. 60

A floor manager's views, hike those of a sponsor, can be entitled to substantial weight. One theory is that "explanatory statenents in the nature of a supplemental report made by the coinmittee meinber in charge of a bill in course of passage" constitute an extension of the cominittee report itself and, therefore, are more rehable than the views of other Members. ${ }^{61}$ The Court's endorseinent of this theory, however, is less than complete.

Typically the committee member who is the fioor inanager of a bill explains the bill's meaning and answers questions. Soinetimes this takes the form of a planned colloquy, where questions and answers on a particular point are agreed to before the debate. Chary of affirming views that might not have received congressional approval if put to a vote, courts sometimes voice suspicion about the planned colloquy. ${ }^{62}$

There are a variety of circumstances in which a colloquy or other explanation by the floor manager may be considered useful. ${ }^{63}$ Ambiguities could be perceived after the committee report has been filed, and parhainentary rules or tactics may preclude a clarifying amendinent. Potential supporters and opponents alike inay try to obtam concurrence with imterpretations that support-or minimize harm to-their interests. There is a natural tendency to explain a bill in a manner calculated to gain support for its passage.

For a long tinie, the Supreme Court has rehed on the colloquy as a valuable part of legislative history to aid in the interpretation of statutes. ${ }^{64}$ The Court recently noted that "statements by individual legisla-

Before we may say that Congress meant to strike from workers' hands the economic weapons traditionally used .... that meaning should plainly appear. ... We would expect that

[such] legislation ... would be preceded by extensive congressional study and debate ....

The silence regarding such matters . . . is itself evidence that Congress . . . had no thought

of prohibiting agreements directed to work preservation.

See also Edmonds v. Campagnie Generale Transatlantique, 443 U.S. 256, 266-67 (1979) ("This silence is most eloquent, for such reticence while contemplating an important and controversial change in existing law is unlikely."); NLRB v. Fruit \& Vegetable Packers, 377 U.S. 58, 66 (1964) ("The silence of the sponsors of amendments is pregnant with significance . . . .").

60. See, e.g., Garcia v. United States, 469 U.S. 70, 78 (1984) (floor inanager's response to another Meinber's objeetion is best read as an attempt by one in favor of the bill to linit its perceived scope). For an account of mutually inconsistent assurances being given to proponents and opponents of a measure during the same debate, sce Mikva, supra note 3 , at 381 .

61. Duplex Printing Press Co. v. Deering, 254 U.S. 443, 475 (1921).

62. See infra text accompanying notes 66-67.

63. For elaboration on the possible uses of colloquies, see Moorhead, A Congressman Looks at the Planned Colloquy and Its Effect on the Interpretation of Statutes, 45 A.B.A. J. 1314 (1959).

64. See, e.g., Binns v. United States, 194 U.S. 486, $495-96$ (1904) (quoting coinınittee chairman's response to inquiries from floor). 
tors should not be given controlling effect, but when they are consistent with the statutory language and other legislative history, they provide evidence of Congress' intent."65 Nonetheless, from time to time, courts raise warning flags in their opimions. In Regan v. Wald, for example, Justice Rehnquist's opimion for the Court cautioned:

To permit what we regard as clear statutory language to be materially altered by such colloquies, which often take place before the bill has achieved its final form, would open the door to the inadvertent, or perhaps even planned, undermining of the language actually voted on by Congress and signed into law by the President. ${ }^{66}$

In another context (contemplation by a conference committee that an agency would not exercise its authority in a particular maimer) the United States Court of Appeals for the District of Columbia Circuit voiced similar fears:

Courts in the past have been able to rely on legislative history for important imsights into congressional intent. Without implying that this is no longer the case, we note that interest groups who fail to persuade a majority of the Congress to accept particular statutory language often are able to have inserted in the legislative history of the statute statements favorable to their position, in the hope that they can persuade a court to construe the statutory language im light of these statements. This development underscores the importance of following unambignous statutory language absent clear contrary evidence of legislative imtent. ${ }^{67}$

In the context of floor debates, the problem is not that these views were introduced imto the "debate," but rather that courts may imininterpret acquiescence in such practices as representing congressional agreement with the substance of the views asserted.68

The niodern rule that views of sponsors and floor managers can be given substantial weight developed as an exception to the old rule that views of mdividual Members were inadmissible to estabhish the meaning of a statute. ${ }^{69}$ Vestiges of the old rule still remaim: Views of Members

65. Brock v. Pierce County, 476 U.S. 253, 263 (1986).

66. 468 U.S. 222, 237 (1984). The reference to the timing of colloquies is puzzling: If the bill language was changed in a material way after the colloquy, then perforce the colloquy loses interpretational value.

67. National Small Shipınents Traffic Conference, Inc. v. Civil Aeronautics Bd., 618 F.2d 819, 828 (D.C. Cir. 1980).

68. Judge (former Congressman) Mikva has suggested that courts need to distinguish "between the 'hot debate' which really tells a reviewing court what was troubling the Congress and what the majority wanted to achieve, and the pas de deux where two meinbers get up and read a congressional version of a psychodrama from a prepared script." Mikva, supra note 26, at 185.

69. Aldridge v. Williams, 44 U.S. (3 How.) 9, 24 (1845) ("[T]he judgment of the court cannot, in any degree, be influenced by the construction plaeed upon it by individual members of Congress in the debate which took place on its passage," but instead must be based on the language "im the act itself ...."). 
who are not associated with either formulation or committee review of legislation ordinarily merit hittle weight $\mathrm{m}$ isolation. But views of individual Members may have cumulative importance in order to show "common agreement" as to broad congressional purpose, ${ }^{70}$ or as to a more refined interpretation by the bill's sponsor. ${ }^{71}$

Views of bill opponents usually are discounted: "The fears and doubts of the opposition are no authoritative guide .... It is the sponsors that we look to when the meaming of the statutory words is in doubt."72 The Court has recognized that, "[i]n their zeal to defeat a bill, [opponents] understandably tend to overstate its reach."73 Thus, a bill opponent's disagreement with the sponsors, floor manager, or the committee report ordinarily will not be given interpretational weight. This does not mean that a court always will adopt a sponsor's explanation rather than an opponent's interpretation. However, if a sponsor's explanation departs too far from the statutory language, a court is more likely to rely on the statute itself rather than attribute the opponents' views to Congress as a whole.

Nonetheless, there are ways im which opponents' views can be given weight. If opponents are in general agreeinent with sponsors as to the purpose or effect (if not the desirability) of the statutory language, then this consensus can be significant. ${ }^{74}$ Also there is the possibility that if the bill's proponents do not answer criticism by opponents, their silence may lend credence to the criticism. Views that could have been readily dismissed as "fears and doubts of the opposition" instead have been relied upon as "relevant and useful" because proponents did not respond to opponents' assertions. ${ }^{75}$

70. FTC v. Raladam Co., 283 U.S. 643, 650 (1931).

71. First Nat'1 Bank v. Walker Bank \& Trust Co., 385 U.S. 252, 259-60 (1966) (quoting several members on their understanding of the purposes of the Banking Act of 1933).

72. Schwegmann Bros. v. Calvert Distillers Corp., 341 U.S. 384, 394-95 (1951); see also United States v. United Mine Workers, 330 U.S. 258, 276-77 (1947) (Court did not accept views of Member who voted against the bill and was not on the cominittee that reported the bill-especially since views conflicted with those of supporters).

73. NLRB v. Fruit \& Vegetable Packers, 377 U.S. 58, 66 (1964).

74. United States v. Dickerson, 310 U.S. 554, 561 (1940). See also United States v. Riverside Bayview Hoines Inc., 474 U.S. 121, 137 (1985) ("even those who would have restricted the reach of the Corps' jurisdiction" agreed that "adjacent wetlands" should fall within jurisdiction); Colorado River Water Conservation Dist. v. United States, 424 U.S. 800, 811 (1976) ("It was unmistakably the understanding of proponents and opponents of [the McCarran Amendment] that it comprehended water rights reserved for Indians.").

75. Arizona v. California, 373 U.S. 546, 583 n.85 (1963) (criticisms of opponent given greater weight by Court since proponents of legislation did not respond to their critique); contra Mastro Plastics Corp. v. NLRB, 350 U.S. 270, 288 (1956) ("unsuccessful minority cannot put words into the mouths of the majority and thus, indirectly, amend a bill"). 
The timing of floor debate or insertions into the Record can vitiate the interpretational value that otherwise might attach to the analysis. Statements inserted into the Record after passage of the bill have been dismissed as "represent[ing] only the personal views of [the] legislators" involved. ${ }^{76}$ Similarly, the Court has rejected reliance on a committeeprepared, section-by-section analysis placed in the Record after consideration of the original bill and the conference report, explaining that the timing "refutes any notion that Congress focused on the precise issue, much less adopted the approach" of the analysis. ${ }^{77}$ Here, as in the general area of post-enactment developments, however, the Court is inconsistent, having on another occasion cited as indicative of congressional imtent a bill summary placed in the Record by the bill's sponsor after passage. ${ }^{78}$

Other potential problems relating to the timing and scope of floor consideration derive from the fact that the Congressional Record is not limited to remarks actually delivered on the floor of Congress. Members may insert imto the Record material not actually spoken on the floor and may revise spoken remarks prior to publication in the daily and permanent Record. The first problein is addressed partially by the requirement that "statements or imsertions ... where no part of them was spoken will be preceded and followed by a 'bullet' symbol"; 79 in addition, the House requires that substantially verbatim accounts of words actually spoken "shall be clearly distimguishable, by different typeface, from material inserted under permission to extend remarks." 80 The Senate, however, has no comparable requirement. Adherence to the rules permitting only technical corrections also minimizes potential mischief from revisions. ${ }^{81}$ Some have alleged, however, that substantive changes can be made under

76. National Woodwork Mfrs. Ass'n v. NLRB, 386 U.S. 612, 639 n.34 (1967).

77. Mohasco Corp. v. Silver, 447 U.S. 807, 823-24 (1980).

78. North Haven Bd. of Educ. v. Bell, 456 U.S. 512, 530-31 (1982) ("The postenactment history of Title IX provides additional evidence of the intended scope of the Title and confirms Congress' desire to ban employment discrimination in federally financed education programs.").

79. Joint Committee on Printing, Laws and Rules for Publication of the ConGRESSIONAL RECORD, printed in 135 CONG. REc. [App. (daily ed. Jan. 3, 1989)] (emphasis added).

80. Joint Committee on Printing, House Supplement to "Laws and Rules for PubLiCATION OF THE CONGRESSIONAL ReCORD"-EFFeCTIVE AUgust 12, 1986, at id.

81. Under the governing rule issued by the Joint Coinmittee on Priuting, revisions "shall consist only of corrections of the original copy and shall not imclude deletions of correct material, substitutions for correct material, or additious of new subject inatter." See supra note 79. Similar restrictions also appear in a House Supplement, supra note 80: "The Congressional Record shall contain a substantially verbatim account of remarks actually made during proceedings of the House, subject to technical, grammatical, and typographical corrections authorized by the Member inaking the remarks involved." 
the guise of technical corrections. ${ }^{82}$ Research does not reveal any cases in which a court has identified a changed ineaning deriving froun a revision or extension of remarks as pivotal to its reading of legislative history, although the Treasury Department recently grappled with such a problem in interpretimg the ban on inportation of uraniun from South Africa. ${ }^{83}$

The nature as well as the timing of floor debate inay be important. If Congress votes on as well as debates the ineaning of a provision, then perhaps the congressional action should be viewed in a different light than ordinary debate. The significance of Congress's rejection of a proposed aniendinent has been interpreted by the courts, and from those cases we can glean certain general principles.

The fact that one House or the other during consideration of a bill rejected an amendment, which, if enacted, would have affected the statute's meaning in a particular case, is not necessarily entitled to interpretational weight. There are a number of possible explanations for why an anıendinent or bill inight not have gained passage. Although it is possible that rejection of an amendment was based on opposition to its substance, it is also possible that the rejection was based on a perceived redundancy, or on inatters wholly unrelated to the inerits. ${ }^{84}$ Thus, there

82. See, e.g., Gregg v. Barrett, 771 F.2d 539, 540 (D.C. Cir. 1985) (dismissing complaint by several Members alleging that Congressional Record "is not a faithful transcript of what actually is said on the floor of the House and of the Senate").

83. The problem arose as the result of a colloquy never spoken on the floor of the Senate but included in the text of a floor statement submitted for printing in the Congressional Record. Apparently as a result of clerical error, the colloquy was omitted from the daily edition of the Record. See Walsh, Case of the Missing Colloquy May Affect S. Africa Sanctions, Wash. Post, Feb. 17, 1987, at A15, col. 1. However, later the colloquy was printed in the permanent edition of the Record. Compare 132 CoNG. Rec. S11,851-52 (daily ed. Aug. 15, 1986) with 132 CoNG. Rec. 21,840 (1986) (permanent edition). At issue was the meaning of statutory language providing that no uranium "may be imported into the United States from South Africa," 22 U.S.C. § 5059 (1988). The inissing colloquy contained the suggestion that the import ban was not intended to apply to importation for the purpose of reprocessing and export, but instead applied only to importation for the purpose of domestic consumption. The Treasury Department, charged with administering this provision, first issued an interim regulation that permitted contmuation of importation for reprocessing and export, while the Department considered public and congressional comments. 52 Fed. Reg. 7274 (1987). But the Treasury Department subsequently issued an interpretation announcing that the interim regulation was being allowed to lapse, and explaining the Treasury's position that in spitc of the colloquy, the enacted language bans importation of all uranium for reprocessing and cxport as well as for domestic consumption. 52 Fed. Reg. 25,576 (1987).

84. For example, in Schneidewind v. ANR Pipeline Co., 485 U.S. 293 (1988), the Court stated:

This Court gênerally is reluctant to draw inferences from Congress' failure to act . . . .

Indeed, those members of Congress who did not support these bills may have been as convinced by testimony that the NGA alrcady provided "broad and complete ... jurisdiction and control over the issuance of securities" as by arguments that the inatter was best left to the States.

Id. at 306; see also McLaughlin v. Richland Shoe Co., 486 U.S. 128, 132 n.8 (1988) (failure to include in an amendment language addressing a judicial interpretation described as "then-prevail- 
is no general presumption that rejection of an amendment has substantive significance.

Nonetheless, weight can be given to Congress's rejection of a bill or amendment if it is clear that Congress considered and rejected the very position argued before the court. ${ }^{85}$ Therefore, a court must look to the explanation for the action (i.e., to the floor statements or committee report) as well as to the language of the rejected proposal. For example, where a House committee struck language in a Senate-passed bill from the House bill "to insure that there be no preemption," 86 and the House version was later agreed to, the Court found the action important to determine the statute's preemptive reach: "While we are correctly reluctant to draw inferences from the failure of Congress to act, it would, in this case, appear improper for us to give a reading to the Act that Congress considered and rejected." 87

Similarly, the choice of the Senate bill version which retained the broad definition of "navigable waters" then in current law, rather than the House version which would have narrowed the definition, overcame the Court's reluctance to "attribute significance to Congress's failure to act." "88 Even in a case in which an invocation of the House rule agamst nongermane amendments had prevented a vote on the inerits of an amendinent, the Court attached significance to a consensus understanding evidenced by extensive floor debate on the inerits that.preceded the ruling on germaneness. ${ }^{89}$

\section{Hearings}

One imight expect that hearings, being further removed from congressional decision points, would be accorded less interpretational weight than floor debates. An examination of case law does not reveal such a sharp distinction, however. Indeed, soinetimes hearimgs are treated in the same manner as floor debates. A renewed focus on statutory meaning rather than on congressional intent could lead to reexamination of the interpretational value of hearings-not to inention repudiation of soine of the usages described below. Both hearings and foor statements

ing" in a memo placed in Congressional Record, is "too slender a reed" on which to infer congressional acquiescence in interpretation).

85. Blau v. Lehman, 368 U.S. 403, 411-12 (1962).

86. Pacific Gas \& Elec. Co. v. Energy Resources Conservation \& Dev. Comm'n, 461 U.S. 190, 220 (1983).

87. Id.

88. United States v. Riverside Bayview Homes, 474 U.S. 121, 137 (1985).

89. Universities Research Ass'n v. Coutu, 450 U.S. 754, 778 (1981) (shaky precedent also involving the understanding of a later Congress rather than the Congress that enacted provision at issue). 
have been described as "the more diffused, less critical parts of the [legislative] process," $" 90$ and both usually take a back seat to committee report explanations. Hearing records are often voluuninous, which can diminish "the probative force of particular entries." 91 Testimony or submissions for the hearing record that are deemed important by the committee often are either incorporated or referred to im the committee report, enhancing their probative force. One should not forget, though, that hearings are close to the initiation of legislation and can be valuable im establishing the general purpose of a bill or the circumstances that gave rise to the perceived need for legislation. When the judicial anind labors to discover the design of the legislature, it does not hesitate to review the hearing record for assistance. ${ }^{92}$

Views of drafters sometimes are gleaned from the hearing record; indeed, hearings represent the principal on-the-record congressional forum for bill proponents who are not Members of Congress. ${ }^{93}$ For instance, testimony of an Adininistration spokesman on an Administration-backed bill has been treated the same as testimony of a draftsman. ${ }^{94}$ When other sources of legislative history do not elucidate congressional intent on a particular issue, sometimes the Court is willing to rely extensively on the hearing record for explanations by Administration spokesmen. ${ }^{95}$ Sintilarly, the Court will give weight to the explanations of a sponsor, whether the explanations occurred at hearings or during floor debate on a bill. ${ }^{96}$ The Court also has declared that postenactment, contemporaneous administrative construction "carries most weight when the administrators participated in drafting and directly made known their views to Congress im comumittee hearings." "97

90. Wald, supra note 1 , at 202.

91. J. Sutherland, StatuTeS AND Statutory Construction $\$ 48.10$ (4th ed. 1984 rev.).

92. As Chief Justice Marshall observed in another context, "[w] here the mind labours to discover the design of the legislature, it seizes everything from which aid can be derived." United States v. Fisher, 6 U.S. (2 Cranch) 358, 386 (1805) (explaining possible resort to title of act to explain ambignous words in text).

93. Committee markup sessions occasionally afford the same opportunity. See Regan v. Wald, 468 U.S. 222, 236 (1984).

94. Foremost-McKesson v. Provident Sec., 423 U.S. 232, 246-56 (1975) (relying also on statements by a subcommittee counsel identified as a "draftsman"); Ernst \& Ernst v. Hochfelder, 425 U.S. 185, 203 n.24 (1976).

95. Id.

96. Dawson Chemical Co. v. Rohm \& Haas Co., 448 U.S. 176, 224 (1980) (White, J., dissenting).

97. Zuber v. Allen, 396 U.S. 168, 192 (1969). The Court's current deferential approach to administrative interpretations renders this point less important. See, e.g., Chevron, U.S.A., Inc. v. NRDC, 467 U.S. 837 (1984) (if Congress has not "directly spoken to the precise question at issue," a "reasonable" administrative interpretation must be upheld); Farina, Statutory Interpretation and the Balance of Power in the Administrative State, 89 ColuM. L. REv. 452 (1989). 
The Court may take pains not to equate views of lobbyists with congressional intent (witness the suspect status of "staged" colloquies), but nonetheless lobbyists' views on occasion have been given interpretational weight. When "interested parties" urge changes in the law and those changes are adopted, their views of the circumstances that require legislative remedy and the purpose and effect of the favored bill may be taken into account. For example, in a situation in which the statute was ainbiguous and committee reports and floor debates were silent on a particular issue, the Court in Dawson Chemical Co. v. Rohm \& Haas Co. rehed heavily on hearings testimony of patent law attorneys who favored the legislation, and on Justice Department testimony in opposition. ${ }^{98} \mathrm{Be}-$ cause several Congresses had considered similar bills before the measure was eventually enacted, the Court was even willing to examine the hearings records over a four-year span. ${ }^{99}$ In another case, Chicago \& Northwestern Rail Co. v. Transportation Union, the Court gave "great weight" to the views of lobbyists because the legislation in question resulted from an agreement between management and labor that was "ratified" by Congress and the President. ${ }^{100}$ On the other hand, views of lobbyists in opposition to a bill are, just as the views of opposing Members, "entitled to little weight," smce opponents "in their zeal to defeat a bill . . . tend to overstate its reach." 101

In the hearings context, there apparently is no presumption that prepared, written statements are preferred over oral testimony. For example, in holding that Congress had not necessarily rejected a position embodied in statutory language that was suggested by a witness at a hearing but not adopted, the Court in Guessefeldt v. McGrath observed that the proposal "was largely in written form, and therefore less likely to have been seen by or to have had impact on the committee members or to reflect their views." 102 This case does not mean, however, that the Court will reject altogether the probative value of written entries in the hearing record. In Shapiro v. United States, the Court even relied heavily on a brief, submitted by the Office of Personnel Administration general counsel as a follow-up to hearings, that was primted in the hearings record as a small-type appendix. These submissions, the Court explained,

98. 448 U.S. at 236. The dissent suggested that the Court should not rummage so deeply into legislative history when there was no support for the Court's "novel" interpretation in committee reports or in statements by sponsors. Id. at 224 (White, J., dissenting).

99. Id. at 202-12 (surveying 1948, 1949, and 1951 hearings on patent revision legislation).

100. Chicago \& N.W.R. Co. v. Transportation Union, 402 U.S. 570, 576 (1971).

101. Emst \& Ernst v. Hochfelder, 425 U.S. 185, 204 n.24 (1976).

102. 342 U.S. 308, 317 (1952). 
are entitled to "at least [the] weight" given to contemporaneous administrative interpretations. ${ }^{103}$

\section{Challenge to the Established Hierarchy}

A recurring theme in Justice Scalia's opinions (sometmes majority opmions) is a questioning of the established convention whereby committee reports are considered the most reliable source of legislative history for discerning congressional intent. In objecting to perceived abuses stemming from over reliance on committee reports, Justice Scalia also questions the underlying assumption that reports represent the collective understanding of Members who are responsible for sliaping the legislation. Instead, he suggests, reports are prepared by committee staff and are not necessarily even read by committee Members-let alone by the vast majority of voting Members not on the recommending committee.

The full flavor of Justice Scalia's aversion to judicial deference to committee reports emerged in his concurring opinion in Blanchard v. Bergeron, ${ }^{104}$ in which the Court cited with approval a committee report's reference to three district court opinions that set forth factors to consider in the award of attorney's fees:

That the Court should refer to the citation of three District Court cases in a document issued by a single committee of a single house as the action of Congress displays the level of unreality that our unrestrained use of legislative history has attained. I am confident that ouly a small proportion of the Members of Congress read either one of the Committee Reports in question, even if (as is not always the case) the Reports happened to have been published before the vote.... As anyone familiar with inodern-day drafting of congressional committee reports is well aware, the references to the cases were inserted, at best by a committee staff member on his or her own initiative, and at worst by a committee staff inember at the suggestion of a lawyer-lobbyist; and the purpose of those references was not primarily to inform the Meinbers ... what the bill meant ... but rather to influence judicial construction. What a heady feeling it inust be for a young staffer, to know that his or her citation of obscure district court cases can transform thein into the law of the land, thereafter dutifully to be observed by the Supreme Court itself. 105

103. 335 U.S. 1, 12 n.13 (1948). Justice Frankfurter's vigorous dissent, however, contended that it "is surely to defy the actualities of the legislative process" to attribute to Congress views expressed only in an appendix to hearings (there having been no mention of the OPA construction in hearings testimony, in coinmittee reports, or during floor debate) and that "great encouragement [is thereby] given to the temptations of administrative officials and others to provide self-serving 'proof' of congressional confirmation for their private views." Id. at 46-48.

104. 109 S. Ct. 939 (1989).

105. Id. at 947. In Pierce v. Underwood, 108 S. Ct. 2541, 2551 (1988), the Court rejected 1985 committee report language purporting to interpret a 1980 statute reenacted without cliange in 1985 
There appear to be two distinct but interrelated theines running throughout Justice Scalia's statutory construction opinions: First, any legislative history is suspect if it is aimed at influencing judicial construction rather than explaining legislative action; and second, committee reports are the principal vehicles for such abuse. It is suggested below that focus on the first, more general problem should lessen or eliminate the need to alter the traditional rules of construction under which committee reports are considered to be generally more rehable than floor statements in explaining statutory language.

\section{A. The Fiction of the "Average Voting Member": Substitute for Committee Reports or the Death Knell for Legislative History?}

If committee reports are inherently suspect, to what should courts turn for more authoritative statements of congressional purpose or intent? Justice Scalia suggested in Blanchard that the appropriate focus should be on "what the voting Meinbers of Congress actually had im mind." $106 \mathrm{He}$ did not elaborate on how judges are to determine this "actual," collective state of mind of 535 individuals. In other opinions, however, Justice Scalia inade it clear that he views investigations into subjective legislative intent as futile. ${ }^{107}$ It appears, therefore, that Justice Scalia's dissatisfaction with rehance on committee reports serves principally to emphasize his general dissatisfaction with reliance on any legislative history, and that he would not substitute increased rehance on floor debates for decreased reliance on committee reports.

Several lower court judges have expressed similar inisgivings about committee reports, but unlike Justice Scalia, have suggested as well that floor debates should be considered at least marginally more rehable. Judge Starr asserted that "only the record of speeches on the floor of either chainber should be considered even minimally probative of Congress's intent, [smce only] those remarks have been heard-however superficially-by members of Congress (albeit a minority in most instances)."108 Judge Easterbrook took the process a step further and suggested that, instead of looking to sponsors or opponents of legislation for explanation, "[i]t would be better to pop the question to the median

The language could not be "an authoritative interpretation" of the 1980 statute, "since it is the function of the courts and not the Legislature, much less a Committee of one House of the Legislature, to say what an enacted statute means."

106. Blanchard, $109 \mathrm{~S}$. Ct. at 947.

107. See infra note 116 .

108. Starr, supra note 2 , at 375-76. 
legislator, the one whose vote could change the outcome."109 If this hypothetical legislator could be identified and his or her answer to the pivotal questions obtamed, then this method would focus a court's attention on whether the bill could have passed if Congress had understood the court's interpretation. ${ }^{110}$ Focus on the actual vote in each House is appropriate, because Congress passes legislation by vote. However, there is no easy way to identify-let alone determine the actual views of - the "average votimg Member." A serious attempt to do so will encounter the usual pitfalls inherent im reliance on floor debates, and could create additional problems.

An "average Member" might be defined as a Member who voted on (or, more appropriately, for) the measure without active involvement in sponsorship, committee consideration, or opposition. The record of floor debates will reveal what explanations were tendered to those Members who were present. However, if these more authoritative explanations are disregarded, there may be little else to go by. Floor debates do not necessarily contaim statements that reflect the views of the more detached Members and seldom contain statements by a large enough number to support a conclusion tliat tliere was a majority or consensus on a particular interpretation. ${ }^{111}$ Almost invariably, one interpretational convention or anotlier must be applied before conclusions can be drawn from a 'floor debate. The best one can expect (in the absence of an actual vote on the interpretational issue presented) is not that a majority of "average" Members will have addressed a particular issue, but instead that one Member may liave sought clarification, that clarification was provided by

109. Easterbrook, supra note 2, at 63 . For a sampling of lower court opinions, see In re Sinclair, 870 F.2d 1340, 1344 (7th Cir. 1989) (Easterbrook, J.) (committee report has less persuasive force than opinion poll of Members, since "the legislative history is written by the staff of a single committee and not subject to a vote or veto"); FEC v. Rose, 806 F.2d 1081, 1090 (D.C. Cir. 1986) (Starr, J.) ("[T]his court sitting en banc has condemned the well-recognized phenomenon of deliberate manipulation of legislative history at the committee level to achieve what likely cannot be won before Congress as a whole ...."); International Bhd. of Elec. Workers v. NLRB, 814 F.2d 697, 715 (D.C. Cir. 1987) (Buckley, J., concurring) ("This case is a classic example of the dangers that can flow from an indiscriminate attempt to read legislative meaning into congressional tea leaves . . . ."); Hirschey v. FERC, 777 F.2d 1, 8 (D.C. Cir. 1985) (Scalia, J., concurring) ("[R]outine deference to the detail of committee reports, and the predictable expansion in detail which routine deference has produced, are converting a system of judicial construction into a system of committee-staff prescription ..." But cf. Overseas Educ. Ass'n v. FLRA, 876 F.2d 960, 974-75 (D.C. Cir. 1989) (repeating cautions about committee reports but calling floor debate "far less reliable").

110. Easterbrook, supra note 2, at 63.

111. Justice Scalia himself has argued that statutory meaning should not be derived "on the basis of which meaning can be shown to have been understood by a larger handful of the Members of Congress." Green v. Bock Laundry Mach. Co., 109 S. Ct. 1981, 1994 (1989) (Scalia, J., concurring). For the rest of the quotation in context, see infra text accompanying note 118. For a discussion of Justice Scalia's aversion to legislative history for statutes (compared with his embracc of legislative history of the Constitution), see Note, supra note 33. 
a reliable source, and that both sponsors and opponents agreed on the correct interpretation. If the explanation was a reasonable one, the Court will assume that general agreement between proponents and opponents is interpretively significant. ${ }^{112}$ Change the situation only slightly, however, and more assumptions must be made. If, for example, a sponsor or committee spokesman answered the Member's inquiry and no other views were expressed on the correct interpretation, then the usual questions about the weight given floor debate may be raised. Was the Member who sought clarification genuinely disinterested, or was the exchange a "staged" colloquy between bill proponents?" Was there a large, presumably attentive audience, or was the exchange slipped into the debate during a sparsely attended session? ${ }^{114}$ More important, was the explanation distorted in order to wm approval, ${ }^{115}$ or was it a reasonable interpretation of the statutory language at issue?

There is no indication that Justice Scalia favors an inquiry into the actual views of voting Members. In fact, he has expressed strong disfavor with probes into subjective legislative intent. As Justice Scaha recently stated, the Court's task is "not to enter the minds of the Members of Congress-who need have nothing in mind in order for their votes to be both lawful and effective-but rather to give fair and reasonable meaning to the text of the United States Code."116

Thus, "what the voting Menibers actually had in mind" may translate in many cases into what reasonable judges believe reasonable legislators should have had in mind when reading and considering the bill language in the context of the bill as a whole. Judge Easterbrook, invoking the "reasonable nuan of tort law," made this translation explicit: "Tle meaning of statutes is to be found not in the subjective, multiple

112. See supra note 74 and accompanying text.

113. Although as a general matter it might seem unimportant whether a particular debate is "staged" or spontaneous, see supra note 68 and accompanying text, the issue may be more important if inquiry focuses on the mindset of the "average" Member.

114. See Mikva, supra note 26, at 185 (recounting an imstance when exaggerated claims "spoken mostly to an empty House" went unanswered). As Justice Rehnquist pointed out,

it is a matter of common knowledge that at any given time during the debate ... the members of either House in attendance on the floor may not be great, and it is only these members or those who later read the remarks in the Congressional Record, who will have the benefit of the floor remarks.

Simpson v. United States, 435 U.S. 6, 17-18 (1978) (Rehnquist, J., dissenting).

115. See supra note 60 and aecompanying text.

116. Pennsylvania v. Umion Gas Co., 109 S. Ct. 2273, 2296 (1989). In his dissenting opimion in Edwards v. Aguillard, 482 U.S. 578, 636 (1987), Justice Scalia advocated abandonment of the "purpose" prong of the Lemon v. Kurtzman test for Establishment Clause validity: "[W] hile it is possible to discern the objective 'purpose' of a statute ... , or even the formal motivation for a statute where that is explicitly set forth ..., discerning the subjective motivation of those enacting the statute is, to be honest, almost always an impossible task." 
mind of Congress but in the understanding of the objectively reasonable person." 117

\section{Justice Scalia has argued for the same approach:}

The meaning of terms on the statute-books ought to be determined, not on the basis of which meaning can be shown to have been understood by a larger handful of the Members of Congress; but rather on the basis of which meaning is (1) most in accord with context and ordinary usage, and thus most likely to have been understood by the whole Congress which voted on the words of the statute (not to mention the citizens subject to it), and (2) most compatible with the surrounding body of law into which the provision must be integrated-a compatibility which, by a berign fiction, we assume Congress always has in mind. ${ }^{118}$

Apparently, it is also a benign fiction to assume that the meaning most in accord with both context and ordimary usage is the ineaning "inost likely to have been understood by the whole Congress"-especially since Justice Scalia rejects actual proof of the meaning endorsed "by a larger handful of the Menibers." In effect, Justice Scalia advocates increased reliance on statutory text and decreased reliance on congressional explanations of any kind.

If bemgn fictions are to be employed, then one nay question why a fiction that focuses exclusively on statutory text should be indulged, but a fiction attributing to the Congress an understanding of the explanations that routimely acconipany legislation should not. Why, in other words, should the Court's approach reject rehance on materials that Congress routimely generates in passing legislation-materials that Congress itself has chosen to rely on in structuring its operations? Because Members "need have nothing in mind" in order for their votes to count, and because it is next to impossible to determine what a inajority of Members had in mind when voting, a court wishing to attribute any purpose or intent to Congress inust necessarily indulge assumptions, conventions, or benign fictions. So why are some fictions used and others rejected as illegitimate?

The short answer is that Congress enacts statutes-not committee reports or floor statements. Therefore, if the statute is clear, congressional intent does not inatter. The appropriate focus is on what the statutory words inean and not on what a particular committee meant, what a group of voting Menibers ineant, or what a hypothetical "average" Member ineant. As Judge Easterbrook suggests, "original meaning" better suminarizes "the interpretive task" than does "original imtent."119 The

117. Easterbrook, supra note 2, at 65.

118. Green v. Bock Laundry Mach. Co., 109 S. Ct. 1981, 1994-95 (1989) (Scalia, J., concurring).

119. In re Sinclair, 870 F.2d 1340, 1343 (7th Cir. 1989). 
Constitution grants Congress power to enact laws; committee reports that represent the consensus views of a single committee-or even of a single House-are no more laws than a committee veto or the one-House veto struck down in Chadha. ${ }^{120}$

However, this "short answer" works only when the statutory words are clear and unambiguous. Words by their very nature are imprecise, and this imprecision is magnified when words are combined in legislation. ${ }^{121}$ There is the distimct possibility that statutory disputes come before courts because of genuine ambiguities in statutory language, especially when the statute is applied to new or unanticipated circumstances. When statutory wording is ambiguous, it makes a difference what bernign fictions or other devices courts utilize to ascertam statutory meaning. Because words depend upon context for meaning, courts should look beyond "[textual] context and ordmary usage" to consider whether the broader context of enactment helps to explam the text's purpose and meaning. ${ }^{122}$ Legislative history contains the best available evidence of both the context and the circuinstances of enactment.

Another consideration raised by Justice Scahia is fairness to "citizens subject to" legislation. Although it may be fair to attribute to the voting Meinbers of Congress a knowledge of interpretations set forth in committee reports that accompany legislation, is it also fair to attribute that knowledge to members of the general public (or to members of a narrower regulated audience) who are subject to the law? In other words, the "benign fiction" may be that Menibers of Congress are deemed to understand the legislation they have approved in the same mauner that judges believe members of the general public (or of a regulated subgroup) would understand the unembellished, unexplained statutory language. As a general matter, few people would disagree that citizens subject to legislation should be able to rely on plaim statutory language. If, however, statutory language is not plain, should the courts then rely upon legislative history for clarification? When statutory language is not plain, it may be useful to distinguish between committee reports and floor debates. The additional burden on citizens and their lawyers to check committee reports is relatively hight when compared to the burden that a rule elevating floor debates to a preferred position would impose. As Justice Jackson asserted years ago, "To accept legislative debates to modify statutory provisions is to make the law inaccessible to a large part of the

120. INS v. Chadha, 462 U.S. 919, 959 (1983).

121. See Frankfurter, supra note 3, at 528-29.

122. The reference is to Justice Scalia's opinion in Green v. Bock Laundry. 
country." 123 Although the Justice's concern in 1951 was with the availability of legislative history materials in all but the larger law firms in the larger cities, accessibility remains a concern today when one considers the cost of paying attorneys routinely to wade through massive quantities of floor debates or hearings records in order to ascertain or verify statutory meaning. This potential burden on the regulated public may temper courts' reliance on legislative history.

In analyzing the burden on citizens and their lawyers, however, the burden of litigation (or of montoring administrative interpretations) also must be weighed. If litigation can be avoided by a clarification of statutory meaming through a search of legislative history, then the expense of that search may be worth undertaking. It is naive to expect that legislative history can frequently clarify issues to the extent of forestalling litigation. ${ }^{124}$ However, well-established rules governing the use of legislative history could imcrease the number of occasions where legislative history will prove useful in resolving ambiguity.

\section{B. Committee Reports}

When courts refer to legislative history to construe statutes, should they continue to rely primarily on relevant committee report explanations? Have good reasons been advanced for why courts should not, in appropriate cases, indulge a bemign fiction that the "considered and collective understandings" of congressional committees are "most likely to have been understood by the whole Congress"? As noted above, Justice Scalia advances strong reasons why committee reports do not necessarily represent the actual views of a majority of voting meinbers (it is unlikely that a majority of members have read the reports), and why some committee report langnage should be discounted because it strays too far from the statutory text. However, if the pursuit of subjective congressional intent is abandoned, and if legislative history is viewed in proper perspective, perhaps as helping to explain ambiguous congressional action but not as an evidentiary coequal to enacted text, then many of the concerns about relying on committee report explanations may give way.

Reliance on committee report explanations has more than a semblance of legitimacy since it reflects the manner in which Congress organizes itself to carry out the task of legislating. Each House delegates to committees the responsibility for initial consideration of legislation; the

123. Schwegmann Bros. v. Calvert Distillers Corp., 341 U.S. 354, 396-97 (1951) (Jackson, J., concurring).

124. For a recent essay describing some of the inherent limits of statutory interpretation, see D'Amato, Can Legislatures Constrain Judicial Interpretation of Statutes?, 75 VA. L. REV. 561 (1989). 
body as a whole relies on committees to sort through thousands of introduced bills, to identify important legislation, to refine and explain that legislation, and to make informed and considered recommendations for passage. Like all large (and overworked) institutions, committees in turn delegate a considerable amount of work to the staff-work that ordinarily includes the drafting of committee reports. If Congress chooses to rely heavily on committees in selecting and shaping legislation, why should courts deny the importance of the committee systein when called upon to give ineaning to the product that ennerges from that system? ${ }^{125}$

The principal reason advanced for denying a primary role to coininittee reports is that they are allegedly the product of "committee-staff prescription" and not the product of committee-inember dehiberations. ${ }^{126}$ Even though committee reports usually are drafted by the staff, committee meinbers' views are not subordinated to those of the staff. A committee ineinber (or even a coinımittee chairman) inay confess to having read a report in less than its entirety, but this confession does not indicate that the ineinber's views are improperly reflected in the report.127 The job of congressional staff is to implement, not to thwart, their bosses' legislative agendas. The responsible committee staffer will write a report that accurately reflects choices inade by the committee during inarkup; other coininittee and Meinber staff, including staff for the minority party, momitor the committee report, offer suggestions about report language, and if these views cannot be accommodated or are sinnly incoinpatible, advise whether to file additional or dissenting views. As pointed out earher, the possibility of appending individual views to a cominittee report serves both as leverage and as a safety valve against comınittee reports that do not represent accurately the views of a committee majority. This possibility also allows mimority and dissenting inembers to highlight controversial issues for the benefit of the rest of the body.

However, the level of coinmittee staff involvement in committee reports, coupled with the lack of a vote on report language, does counsel caution with respect to detailed report language not closely tied to bill language (and not incorporated into the bill by express reference). ${ }^{128}$

125. This idea was articulated by Chief Judge Patricia M. Wald of the United States Court of Appeals for the District of Columbia Circuit in an address at U.S. Law Week's Constitutional Law Conference, Washington, D.C., given on September 8, 1989. See 58 U.S.L.W. 2200, 2208 (1989) (summary).

126. Hirschey v. FERC, 777 F.2d 1, 8 (D.C. Cir. 1985) (Scalia, J., concurring).

127. See id. at 7 n. 1 (quoting exchange between Senators Armstrong and Dole revcaling that the latter, as chairman of the Finance Committee, had not read im its entirety the Committee's report on major tax legislation).

128. Incorporation of committee reports by reference is not unprecedented, and may become more common if Congress perceives that courts will not otherwise rely on committee reports for 
Although evident departures from committee understandings on important issues may be brought to hight, the possibility is greater that subtle shading on minor issues will escape notice. In fact, Justice Scalia's most vehement attacks on over rehance on committee reports occur in this latter situation. Thus, in Blanchard v. Bergeron he objected to the citation of "obscure district court cases" in a report that purported to explain what constitutes "reasonable" attorney's fees;"129 in Pierce v. Underwood he objected to rehance on a report citation of a minority interpretation of a provision reenacted without change; ${ }^{130}$ and in Hirschey v. FERC he objected to rehance on a report's reference-again in the context of reenactment without change-to appeals courts' rulings on an issue where there was a spht of authority among circuits. ${ }^{131}$ There is a difference, then-Judge Scalia contended, between relying on committee reports for "broad outlines of purpose" and relying on reports for "details" represented by references to decisions of the lower courts. ${ }^{132}$ Likewise, a difference exists between a detailed explanation that is a logical outgrowth of statutory language and a detailed assertion that contrasts sharply with statutory generality.

In spite of these limitations, reference to committee reports may enable a court to resolve ambiguity in a inanner consistent with explanations provided by the committees that were delegated authority to screen and shape legislation for each House. Certainly, Congress only enacts statutory language, but enactment is often a vote to accept the recoinmendations of a standing committee or of a conference committee. If there are two equally plausible interpretations of statutory language, one that is actually endorsed in a committee report accompanying enactment and one that is not, should a court then be free to choose between the two, or should the court pick the interpretation advanced during consid-

congressional explanation. As an example of incorporation by reference, the Budget Reconciliation Act of 1987, Pub. L. 100-202, § 107, 101 Stat. 1329-1, 1329-434 provides: "Amounts and authorities provided by this resolution shall be in accordance with the reports accompanying the bills as passed by or reported to the House and Senate and in the Joint Explanatory Statement of the Conference accounpanying this Joint Resolution."

Moreover, for 12 of the 13 appropriations ineasures included in the Continuing Resolution, the referenced Joint Explanatory Statement also contained detailed instructions for resolving conflict in report language (basically, that House or Senate report language is to govern unless expressly contradicted by the resolution or by the conferee's joint statement). For one such set of instructions, see H.R. REP. No. 495, 100th Cong., 1st Sess. (1987), reprinted in 133 CoNG. REC. H12,774 (applying to the appropriation for Rural Development, Agriculture, and Related Agencies).

129. 109 S. Ct. 939, 947 (1989) (emphasis added).

130. 108 S. Ct. 2541, 2550-51 (1988).

131. 777 F.2d 1, 6-8 (D.C. Cir. 1985) (Scalia, J., concurring).

132. Id. at 7. 
eration of the legislation? ${ }^{133}$ To allow the court to choose freely permits the hypothetical "reasonable person" to operate in a vacuum, freed from the context and circumstances that gave birth to the language. To say that the court should pick the committee explanation is to say that the court should consider how a hypothetical reasonable legislator would have interpreted the language as presented in the context of the legislative process, or at least to say that a court should rely on context to choose among alternative meanings.

Another consideration that bears on the legitimacy of reliance on committee reports relates to the reasonable expectations of legislators ("average Members") who vote on legislation. The existing legal landscape shapes those expectations. If the conventions or benign fictions used by courts to interpret legislation are well estabhished and understood, then it becoines inore reasonable to hold legislators to constructive notice of those conventions. At least until recently, Members have known that courts look first to committee reports when explanation of statutory language is needed or desired. Given this convention, a Meinber concerned about how his or her vote will be interpreted could be expected to refer to the committee report for explanation of the bill's purposes and effects, rely upon the explanation of the committee chairman or floor manager, or question the floor manager during debate. ${ }^{134}$ Therefore, courts should rely on a presumption that Members who voted in favor of legislation endorsed (or acquiesced in) the reasonable committee explanations of enacted bill language.

A related inquiry focuses on the likely effect of the interpretational rule on legislative behavior. Assume, for example, that clarification of

133. A related question, largely beyond the scope of this Article, is why should courts be more deferential toward administrative interpretations of statutes than toward committee reports or other congressional interpretations reasonably attributable to Congress as a whole. Under Chevron, U.S.A., Inc. v. NRDC, 467 U.S. 837 (1984), courts defer to "reasonable" or "permissible" administrative interpretations, $i d$. at 843 , unless "Congress has directly spoken to the precise question at issue." Id. at 842 . The assumption that Congress necessarily and implicitly delegates to agencies such broad discretion to interpret statutes is, arguably, no more plausible than the assumption that a House of Congress endorses reasonable cominittee explanations when it approves legislation recommended by that committee.

134. Note that there are a variety of ways in which a Member might inform himself about committee or sponsor explanations. The fact that a Member was not actually present on the floor during portions of debate on a bill does not mean that the Member was not, either personally or by staff, monitoring debate on C-Span in his office, or did not, prior to voting, read relevant portions im the Congressional Record. Likewise, staff may have attended hearings or markup, read transcripts of those proceedings, obtained committee reports, or consulted with committee staff, in order to inform the Member. Doubtless courts would be reluctant to rely on the possibility of such monitoring to conclude that Members were actually aware of particular explanations, but the fact that such possibilities exist may make a "constructive notice" convention more reasonable. 
statutory text is the desired end. ${ }^{135}$ The question becomes whether the traditional interpretational approach induces Members to attempt to clarify the statute by amendment rather than by ineans of explanatory history. If all legislative history is disregarded in favor of a court's view of the "ordinary usage" in a textual context, then presumably Meinbers who oppose the ordinary meaning of statutory language-or who are uncertain as to what ordimary ineaming courts might read into a provisionwould conclude that their only recourse is to offer a clarifying amendment. This would be true for both committee Meinbers and "average" Members. If a clearly worded amendinent passes, then the sponsor achieves her purpose. On the other hand, if the amendment is defeated, then under a strict rule denying resort to debates (or to committee proceedings), the defeat would not be weighed against the sponsor's interpretation. Similarly, if committee reports may be consulted but floor debates may not, then non-committee Members have no incentive to atteinpt to clarify the statute through colloquies or other floor debate. However, non-committee members still have incentive to offer a clarifying amendment. By contrast, committee Members might choose between two courses of action: to offer an amendment in committee or attempt to influence committee report language. If, on the other hand, both committee reports and floor debate are given interpretational weight, then Members would have imcentive to attempt to influence interpretation by way of both debate and amendment. The amount of incentive depends upon the relative interpretational weight given. If legislative history is considered subordmate to statutory language, then Members will know that the amendment route, if successful, will be more likely to establish a particular interpretation. Likewise, the goal of clarifying statutory text is not necessarily thwarted by a rule that allows reference to legislative history as long as that history is viewed as subordinate to text.

\section{What Role for Floor Debates?}

Adherence to the established rule that coinmittee report explanations generally carry inore persuasive force than conflicting floor statements does not mean that rehance on floor statements need be discarded altogether. Unless the entire legislative record has been examined to de-

135. Assume also that the bill is debated under a procedural rule that permits amendment. This is not always the case. Under House procedures, for example, some bills come to the floor under "restricted" or "closed" rules that limit or prohibit amendment, or under a suspension of the rules that also precludes amendment. See generally C. TIEFER, supra note 20, at 284 (types of rules), 296 (suspension). Moreover, although it used to be true that Congress debated the vast majority of bills under "open" rules allowing amendmeuts, during the 1970s and 1980s Congress has turned increasingly to restrictive rules. Id. at 291-93. 
termine the critical stages in adoption of the language, rehance on cominittee reports inay be misplaced. As noted above, some statutory language originates in floor amendments not considered in committee; in those circumstances, if clarification or background information is desired then one must necessarily look to the remarks of the sponsor and to other floor debate. On other occasions, totally unrelated measures may be combined in book-length contmuing resolutions or omnibus budget reconciliation bills that provide Members with little or no cliance to check their interpretations with explanations contained in committee reportsif, in fact, such explanations exist. ${ }^{136}$ In the unlikely event that a floor manager's statement slieds light on such an interpretation, the statement should not automatically be subordinated to a committee report explanation.

Moreover, there are other instances when reference to floor action or debate inay help to clarify enacted language. Issues may be raised that were not explored in the committee report, or votes may be taken on proposed amendments that reveal a congressional decision that affects interpretation of the enacted language. ${ }^{137}$ In rare instances, floor inanagers may contradict or correct erroneous or misleading explanations in the staff-prepared committee report. ${ }^{138}$ More frequently, reference to floor statements inay show that the same points emphasized in committee reports also were made by a bill's floor inanager, and hence, were brought to the attention of voting Members by the two best means available. Thus, if legislative history is consulted there is no easy way to focus exclusively on committee reports without also cliecking floor action, and on some occasions floor statements may be more informative and probative than coinmittee explanations.

If floor debate is consulted, then adlierence to the traditional rules of construction governing the use of floor statements may help reduce confusion. For example, if only explanations by sponsors or floor managers are given significant weight, then conflicts between floor debate and committee report explanations should be relatively uncommon. Siinilarly, the traditional rules provide a way for courts to weed out some of the conflicting views expressed in floor statements. On the other hand, more

136. For example, in News America Publishing, Inc. v. FCC, 844 F.2d 800, 807 (D.C. Cir. 1988), the fact that a little-noticed amendment had been hidden in a 471-page continuing resolution and "had received no comment whatsoever in any congressional committee or on the floor of either house" seemingly strengthened the court's resolve in holding the amendment unconstitutional. Of course, if Congress enacts such a measure with committee reports incorporated in the bill by express reference, see supra note 128 , then for interpretational purposes it should not matter whether Members have had a fair chance to refer to the reports.

137. See supra notes $84-89$ and accompanying text.

138. See supra note 11 and accompanying text. 
conflict may be expected if all congressional voices are considered equal or if the views of the mythical "average" voting Member are sought.

Although it is axionatic that each Member's vote counts the same as any other's, each congressional voice need not be given equal weight in interpreting a statute. Even if the "average" Menber's vote controls, views of opponents should be discounted (except when those views coincide with proponents' views and help demonstrate consensus). The difference occurs in how courts account for the views of those Members who vote in favor of legislation but who are not among the favored fewi.e., Members who are not sponsors, floor managers, or even reporting committee members. Again, unless a groundswell of support appears for a position contrary to that of the floor manager or other bill spokesperson, it may be reasonable to assume that most Members who voted in favor of the bill accepted the tendered explanation. This rule is consonant with congressional practice: When explanations of bill language are desired, a Member ordinarily will address her question to either the sponsor or the floor manager. ${ }^{139}$ To rule that one dissonant voice-even from a Member who votes im favor of a bill-can negate an otherwise reasonable explanation by a bill's manager would render useless almost all reference to floor debates and also would invite mischief.

\section{CONCLUSION}

Perhaps a good case can be made for reordering the interpretational hierarchy courts apply to choose among the various sources of legislative history. Except at the most general level of theory, however, the case has not yet been inade for customarily valuing floor debates ahead of committee report explanations. Certainly there are occasions when committee reports do not aid in imterpretation and when other sources (e.g., a floor manager's or sponsor's explanation) may be illuminating. The rule that a clear committee report explanation is always to be preferred to contrary explanation by a bill's floor manager (usually the chairman of the committee or subcommittee of jurisdiction) inay even be questioned. Partly for these reasons, any approach to reliance on legislative history must inaintain sufficient flexibility to permit courts to identify and focus upon the key stages in the adoption of the language at issue without automatically excluding from consideration either cominittee reports or floor debates. Nonetheless, in the ordinary course of legislation, committee reports should be looked to for the most coherent, thorough, and authoritative explanation of a bill's purpose and intended meaning. To abandon

139. This is the same point Judge Wald makes with respect to committee reports. See supra note 125 and accompanying text. 
altogether reliance on committee reports not only ignores the way Congress customarily operates, but also denies access to the best source of congressional explanation.

Even though committee reports sometimes contain extraneous material and sometimes courts improperly rely on such material, these facts do not niean that committee reports are generally invalid sources to aid in the ascertainment of statutory neaning. One can agree with an appellate court's admonition that "it is plainly wrong as a general matter ... to regard committee reports as drafted nore meticulously and as reflecting the congressional will inore accurately than the statutory text itself," 140 without agreenig that committee reports are drafted less meticulously and explam statutory meaning (or a bemgnly fictional "congressional will") less accurately than floor debates, hearings, or other sources of legislative history. If the courts use legislative history to explain statutory text and not to supplant it (i.e., if statutory ineaning is not to be confused with congressional intent), then the general rule that favors committee report explanations, as well as many of the other rules and conventions that determine the relative interpretational value of legislative history, still provide useful gnidance.

140. Abourezk v. Reagan, 785 F.2d 1043, 1054 n.11 (D.C. Cir. 1986) (emphasis added). 